\title{
MENINGKATKAN KEMAMPUAN PEMECAHAN MASALAH MATEMATIKA SISWA PAKET B DAN C DI PKBM MENTARI FAJAR MENGGUNAKAN METODE POLYA
}

\author{
I. W. Sumarjaya ${ }^{1}$, M. Joni ${ }^{2}$, N. N. Rupiasih ${ }^{3}$, dan J. Sibarani ${ }^{4}$
}

\begin{abstract}
ABSTRAK
Sebagai suatu institusi pendidikan nonformal yang kepemilikan dan pengelolaanya dilakukan oleh masyarakat Pusat Kegiatan Belajar Masyarakat (PKBM) menjadi tempat melanjutkan pendidikan bagi siswa putus sekolah. Observasi pada awal Februari 2017 di PKBM Mentari Fajar menunjukkan bahwa sebagian besar siswa Paket B dan C mengalami kesulitan dalam memecahkan masalah matematika misalnya operasi pecahan dan pangkat. Matematika sebagai salah satu bidang dasar yang diperlukan dalam penguasaan sains dan teknologi tentu pemahaman dan penguasaannya, khususnya dalam memecahkan masalah matematika, sangat diperlukan. Kegiatan pengabdian ini diawali dengan melakukan survei berupa pemberian kuesioner kepada guru pengajar matematika dan siswa Paket B dan $\mathrm{C}$ yang bertujuan untuk melihat kelemahankelemahan dalam memecahkan masalah matematika. Selanjutnya dilakukan pelatihan berupa strategi pemecahan masalah baik secara individu maupun tim. Materi pelatihan meliputi pemahaman tentang logika, pengenalan metode Polya, strategi belajar matematika, dan teknik mnemonic untuk mengingat rumus matematika. Setelah workshop dilakukan evaluasi berupa pemberian kuesioner dan soal pascauji kepada para siswa. Berdasarkan hasil analisis data dapat disimpulkan bahwa pelatihan mampu meningkatkan kemampuan siswa dalam menyelesaikan masalah matematika.
\end{abstract}

Kata kunci : pendidikan kesetaraan belajar masyarakat, penyelesaian masalah matematika, metode Polya, strategi belajar matematika, teknik mnemonic.

\begin{abstract}
As a nonformal eductional institution in which ownership and governance are conducted by community, community learning centre (CLC) has been the place for school dropouts to continue their education. Observation in early February 2017 at the Mentari Fajar CLC concludes that almost all students of Paket B and Paket $\mathrm{C}$ have problem in understanding and solving mathematical problem for instance fraction and power operation. Mathematics which serves as a foundation for science and technology needs to be understood and mastered. One particular area that needs to be acquired is problem solving. This community service starts by distributing questionnaires to teachers and students Paket B and C to seek weakness in mathematical problem solving skills. The workshop which serves as the core program consists material such as applying mathematical logic, introduction to Polya method, learning strategy and mnemonic technique to memorize formulas. Three weeks after the workhshop monitoring and evaluation are conducted. The monitoring and evaluation aim at obtaining students response to the posttest and feed to the program. Based on data analysis we conclude that the workshop is able to increase students' mathematical problem solving skills.
\end{abstract}

\footnotetext{
${ }^{1}$ Program Studi Matematika, Fakultas MIPA, Universitas Udayana, sumarjaya@unud.ac.id

${ }^{2}$ Program Studi Biologi, Fakultas MIPA, Universitas Udayana, martinjoni.mj@gmail.com

${ }^{3}$ Program Studi Fisika, Fakultas MIPA, Universitas Udayana, rupiasih@gmail.com

${ }^{4}$ Program Studi Kimia, Fakultas MIPA, Uniiversitas Udayana, sibaranijames@gmail.com
} 
Keywords: community learning centre, mathematical problem solving, Polya method, learning strategi for mathematics, mnemonic technique

\section{PENDAHULUAN}

Pendidikan Kesetaraan Belajar Masyarakat (PKBM) merupakan salah satu bentuk institusi pendidikan nonformal yang dimiliki dan dikelola oleh masyarakat. Keberadaan PKBM diatur di dalam Undang-Undang Republik Indonesia Nomor 23 Tahun 2003 tentang Sistem Pendidikan Nasional, khususnya pasal 26. Sebagai lembaga pendidikan nonformal PKBM membantu siswa yang telah putus sekolah atau belum sempat menyelesaikan pendidikan formal.

Yuaelawati et al. (2008) mengatakan ada lima faktor yang menyebabkan penduduk terhambat melanjutkan pendidikan formal yaitu ekonomi, waktu, geografi, keyakinan, dan masalah sosial/hukum. Penjelasan rinci tentang faktor ini dapat dilihat pada Yuaelawati et al. (2008). Wawancara dengan pengelola PKBM yang dilakukan pada akhir Januari sampai awal Februari 2017 memperoleh faktor lain yang menyebabkan siswa untuk melanjutkan pendidikan di PKBM adalah faktor kejiwaan siswa dan tuntutan tempat kerja. Yang dimaksud dengan faktor kejiwaan ialah kejadian yang membuat siswa merasa tidak nyaman belajar pada sekolah formal karena tekanan atau ekspresi yang tidak tersalurkan, sehingga siswa yang bersangkutan memutuskan untuk melanjutkan pendidikan di PKBM. Faktor tuntutan tempat kerja mengacu kepada munculnya penjenjangan karir pada tempat kerja para siswa yang membutuhkan legalitas berupa ijazah.

PKBM Mentari Fajar menyelenggarakan pendidikan kesetaraan Paket A, Paket B, dan Paket C. Khusus untuk program Paket C, PKBM ini memiliki program kesetaraan untuk ilmu pengetahuan sosial (IPS). Berdasarkan studi awal berupa wawancara dengan pihak pengelola PKBM pada awal Februari tahun 2017 diperoleh hasil bahwa siswa Paket B dan Paket C mengalami kesulitan dalam memahami pelajaran matematika dan terutama menyelesaikan soal-soal berbentuk cerita. Kesulitan ini terjadi secara berulang-ulang setiap semester.

Observasi terhadap siswa 20 orang siswa Paket B dan Paket C menghasilkan data sebagai berikut berikut. Masalah utama yang dihadapi oleh siswa Paket B adalah bagaimana memecahkan masalah-masalah dalam materi pelajaran aljabar, persamaan, dan pertidaksamaan. Sedangkan, observasi terhadap siswa Paket $\mathrm{C}$ menunjukkan masalah yang perlu mendapatkan pendalaman adalah akar pangkat, trigonometri, turunan, dan integral. Beberapa faktor yang dapat teridentifikasi pada observasi sebagai penyebab kurangnya kemampuan dalam memecahkan masalah matematika adalah sebagai berikut. Pertama, materi yang cukup susah dan padat sehingga memerlukan waktu yang lebih untuk latihan mengerjakan soal dan belajar. Di lain pihak, para siswa tersebut sebagian besar sudah bekerja sehingga kesulitan dalam mengatur waktu untuk belajar. Kedua, kurangnya pemahaman tentang teknik atau strategi dalam penyelesaian masalah matematika. Pengamatan terhadap contoh buku digunakan untuk Paket B seperti Hasan and Anggraeni (2007) dan untuk Paket C seperti Hidayat (2010) dan Hidayat (2015) dapat disimpulkan bahwa materi pada bukubuku tersebut masih sulit dipahami siswa.

Berdasarkan hasil wawancara dan observasi tersebut di atas disimpulkan bahwa para siswa Paket B dan Paket $\mathrm{C}$ memerlukan teknik dan strategi dalam memecahkan masalah-masalah dalam pelajaran Matematika. Kegiatan yang sesuai untuk permasalahan ini adalah pelatihan yang melibatkan peran serta aktif siswa dan bersifat interaktif dengan pemateri pelatihan.

\section{METODE PELAKSANAAN}

Tahap pemecahan masalah untuk mengatasi masalah tersebut di atas adalah sebagai berikut. Pertama, para siswa Paket B dan C dikelompokkan untuk selanjutnya dilakukan observasi lebih 
lanjut untuk mengetahui materi-materi apa saja benar-benar yang tidak dimengerti. Pada tahap ini diberikan prauji (pretest) berupa kuesioner dan tes soal-soal matematika dengan sumber acuan buku karangan Hasan and Anggraeni (2007) untuk siswa Paket B dan buku Hidayat (2010) dan Hidayat (2015). Tingkat kesulitan soal dirancang agar memenuhi standar kompetensi dasar. Kedua, hasil prauji pada langkah pertama selanjutnya dianalisis. Hasil analisis berisi ringkasan permasalahan secara rinci sebagai dasar dalam pembuatan materi pelatihan teknik dan strategi pemecahan masalah matematika untuk siswa Paket B dan C. Rangkuman permasalahan ini dikoordinasikan dengan pengelola dan pengajar di PKBM Mentari Fajar untuk mendapatkan masukan lebih lanjut.

Hasil analisis pada langkah kedua selanjutnya dijadikan acuan untuk menyusun materi pelatihan oleh tim pengabdi. Materi pelatihan meliputi pengenalan metode Polya dalam penyelesaian masalah. Secara garis besar metode Polya terdiri atas empat langkah: memahami masalah membuat rencana, melaksanakan rencana, dan melihat kembali. Tahap memahami masalah meliputi mengetahui apa yang "tidak diketahui", mengetahui data apa saja yang tersedia, dan apa saja kondisinya. Tahap kedua adalah membuat rencana. Pada tahap ini, masalah-masalah sejenis dan telah diselesaikan sebelumnya dicatat untuk kemudian dilihat apakah bisa digunakan atau tidak. Tahap ketiga adalah melaksanakan rencana. Tahap ini meliputi pemeriksaan langkah demi langkah dan memeriksa apakah langkah-langkah yang dilakukan sudah benar. Tahap terakhir adalah melihat kembali yang meliputi pemeriksaan ulang hasil dan melihat apakah hasil yang telah diperoleh bisa digunakan untuk masalah lain. Metode pemecahan masalah ini dapat dilihat lebih lanjut pada Polya (1975).

Tahap terakhir berupa evaluasi yang dilakukan untuk melihat apakah pelatihan efektif meningkatkan kemampuan siswa PKBM Paket B dan C dalam memecahkan masalah-masalah dalam matematika baik dalam pembelajaran di kelas maupun kegiatan belajar mandiri. Tahap ini penting sebagai bahan evaluasi terhadap kegiatan yang telah dilakukan dan menjadi dasar bagi kegiatan-kegiatan pengabdian lanjutan.

\section{HASIL DAN PEMBAHASAN}

Kuesioner diberikan pada tanggal 1 Agustus 2017 dan umpan balik diterima tanggal 15 Agustus 2017. Kuesioner ini diisi oleh seorang siswa paket B dan 14 orang siswa Paket C. Selain itu, kuesioner ini juga diberikan kepada dua guru matematika: satu orang pengajar Paket B dan satu orang pengajar Paket C. Lima belas siswa mengatakan susah memahami rumus, tidak suka matematika, atau materi sulit dipahami. Tujuh siswa mengatakan ketidakmampuan siswa dalam pengayaan soal-soal atau tidak mampu menjawab soal yang belum pernah dijelaskan. Rincian kuesioner dapat dilihat pada laporan akhir Sumarjaya et al. (2017). Selanjutnya guru pengajar matematika Paket B dan Paket C memberikan masukan sebagai berikut (lihat Tabel 3.1). 


\section{W. Sumarjaya, M. Joni, N. N. Rupiasih, dan J. Sibarani}

Tabel 3.1 Hasil kuesioner guru matematika

\begin{tabular}{|c|c|}
\hline Tanggapan guru & Komentar \\
\hline Paket B & $\begin{array}{l}\text { 1. Materi dasar atau konsep perlu diperkuat } \\
\text { 2. Siswa sulit memahami rumus baru } \\
\text { 3. Siswa sulit memahami atau menelaah soal }\end{array}$ \\
\hline Paket C & $\begin{array}{l}\text { 1. Materi dasar atau konsep perlu diperkuat, misalnya operasi } \\
\text { perkalian } \\
\text { 2. Materi yang sulit dipahami antara lain: pecahan, persamaan } \\
\text { dan pertidaksamaan linear, trigonometri, fungsi, program } \\
\text { linear, turunan, dan integral. } \\
\text { 3. Siswa sulit memahami rumus baru } \\
\text { 4. Siswa sulit memahami soal cerita } \\
\text { 5. Terbatasnya waktu siswa untuk belajar karena sebagaian } \\
\text { besar sibuk bekerja }\end{array}$ \\
\hline
\end{tabular}

Pelatihan berupa workshop sehari dilakukan pada hari Sabtu, 14 Oktober 2017. Target peserta pelatihan adalah 25 siswa Paket B dan C. Namun, separuh peserta yaitu 12 orang tidak hadir karena kerja, acara keagamaan, dan alasan lain.

Pelatihan dimulai dengan memperkenalkan tim pengabdian. Selanjutnya peserta pelatihan mendapat prauji (pretest) berupa soal yang harus dikerjakan dalam waktu 1 jam. Setelah siswa Paket $\mathrm{B}$ dan $\mathrm{C}$ mengerjakan soal, selanjutnya tim pengabdian mulai memberikan pelatihan mengenai metode Polya untuk memecahkan masalah matematika. Tujuan pokok dari pelatihan ini adalah bagaimana siswa Paket B dan C dapat memahami dan kemudian menerapkan teknik dan strategi dalam memecahkan masalah matematika. Materi pertama yang diberikan berupa metode Polya yang diperjelas lagi dengan mendemonstrasikan cara menghitung diagonal ruang tempat pelatihan. Materi selanjutnya adalah strategi mengingat rumus matematika. Teknik yang diajarkan ditekankan pada metode mnemonic. Metode mnemonic ini memudahkan siswa mengingat rumus karena siswa bisa mengasosikan rumus dengan benda atau hal yang disukai. Sebagai contoh tim menjelaskan cara mengingat luas lingkaran dengan mengasosikan $\pi$ sebagai kue (pie) dan jari-jari sebagai penngulung tepung.

Selama workshop berlangsung beberapa siswa Paket B dan C aktif bertanya kepada tim dan seorang peserta bertanya penerapan metode Polya dalam menyelesaikan masalah IPA. Hal ini mengindikasikan antusias siswa dalam mengikuti pelatihan. Pelatihan diakhiri dengan pembahasan soal-soal pada saat prauji. Pembahasan ditekankann pada penggunaan metode Polya. Secara garis besar, para siswa merasakan manfaat pelatihan terutama bagi siswa yang pada awalnya membayangkan susahnya menghafal rumus atau mengerjakan soal-soal matematika.

Pelatihan berupa workshop sehari dilakukan pada hari Sabtu, 14 Oktober 2017. Target peserta pelatihan adalah 25 siswa Paket B dan C. Namun, separuh peserta yaitu 12 orang tidak hadir karena kerja, acara keagamaan, dan alasan lain. Gambar 3.1 memperlihatkan siswa Paket B dan C yang mengerjakan soal prauji. Demonstrasi penerapan metode Polya dalam penyelesaian masalah diagonal ruang dapat dilihat pada Gambar 3.2. 


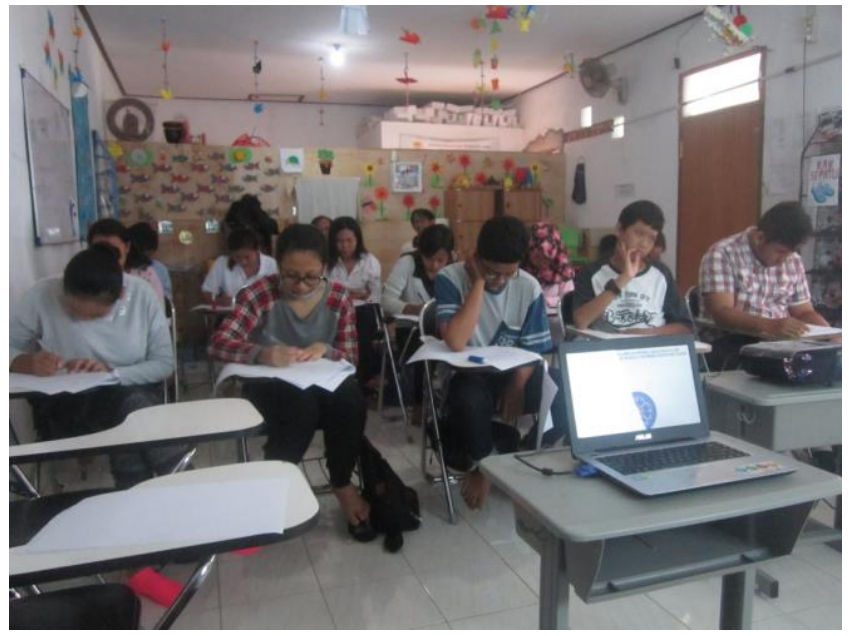

Gambar 1. Siswa Paket B dan C mengerjakan soal prauji yang diberikan.

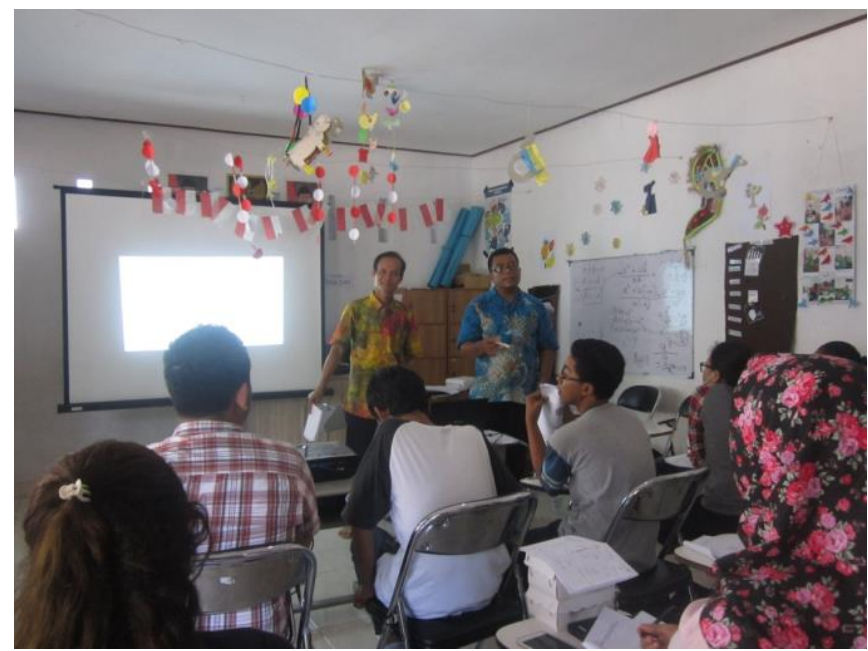

Gambar 2. Demonstrasi tim pengabdian dalam penyelesaian masalah diagonal ruang.

Evaluasi terhadap kegiatan workshop dilakukan pada tanggal 9 November 2017. Kegiatan ini berupa pemberian soal pascauji untuk melihat apakah ada perubahan dalam hal kemampuan memecahkan masalah. Secara garis besar terdapat peningkatan dalam penyelesaian masalah. Hal ini dapat dilihat dari jawaban yang diberikan oleh para siswa.

Berikut ini adalah nilai prauji dan pascauji siswa Paket B dan C. Sebagai catatan soal prauji dan pascauji memiliki tingkat kesulitan yang sama dan pada kegiatan pengabdian ini ingin dilihat apakah metode Polya yang telah diajarkan mampu meningkatkan kemampuan pemecahan masalah matematika. Sebagai catatan terdapat dua siswa yang tidak memberikan jawaban pada saat pascauji dan dua siswa lagi tidak menjawab sesuai dengan instruksi yang diberikan. Jawaban siswa pada saat prauji dan pascauji beserta nilainya secara rinci dan lengkap dapat dilihat pada pada laporan akhir Sumarjaya et al. (2017). 
Berdasarkan laporan akhir tersebut terdapat jawaban dengan nilai nol yang tidak sesuai dengan harapan. Hal ini dapat disebabkan siswa tidak memiliki persiapan atau memang tidak paham sama sekali dengan soal yang diberikan. Nilai pascauji menunjukkan adanya perubahan yang cukup signifikan, meskipun terdapat tiga siswa dengan perubahan yang tidak terlalu drastis. Uji kenormalan terhadap nilai prauji menghasilkan $\mathrm{p}$-value $=0,007732$ yang mengindikasikan ketidaknormalan data pada tingkat signifikansi $\alpha=0,05$; selanjutnya, untuk data pascauji diperoleh $\mathrm{p}$-value $=0,1759$ yang mengindikasikan kenormalan tidak ditolak. Mengingat data prauji dan pascauji tidak keduanya normal, langkah selanjutnya adalah menggunakan prosedur nonparametrik. Pengujian Uji Wilcoxon bertanda dengan hipotesis nol median prauji lebih besar atau sama dengan median pascauji dan hipotesis alternatif media prauji lebih kecil dari median pascauji. Uji ini menghasilkan $\mathrm{p}$-value $=0,007074$. Hal ini mengindikasikan bahwa pada tingkat signifikansi $\alpha=0,05$ tidak cukup bukti untuk menerima hipotesis nol. Dengan demikian, workshop pemecahan masalah matematika ini mampu meningkatkan kemampuan pemecahan masalah matematika siswa Paket B dan C di PKBM Mentari Fajar.

\section{KESIMPULAN DAN SARAN}

Secara garis besar pelatihan mampu meningkatkan kemampuan pemecahan masalah matematika siswa Paket B dan C di PKBM Mentari Fajar. Lebih lanjut lagi, siswa mengharapkan waktu pelatihan diperpanjang. Hal ini mengindikasikan antusiasme siswa dan tentu saja merupakan hal positif yang layak dilanjutkan dalam bentuk program pengabdian lanjutan atau serupa. Mengingat umpan balik dan antusiasme ini pelatihan dapat diperpanjang lagi dan lebih intensif.

\section{UCAPAN TERIMA KASIH}

Ucapan terima kasih disampaikan kepada Rektor Universitas Udayana melalui Ketua Lembaga Penelitian dan Pengabdian Masyarakat Universitas Udayana atas pendanaan kegiatan pengabdian ini yang bersumber dari DIPA PNBP Universitas Udayana Tahun Anggaran 2017 Sesuai dengan Surat Perjanjian Penugasan Pelaksanaan Hibah Pengabdian kepada Masyarakat Udayana Mengabdi Nomor: 67448/UN14.4.A/PM/2017, tanggal 12 Juli 2017. Terima kasih juga disampaikan kepada pihak PKBM Mentari Fajar dan para siswa paket B dan C yang telah berpartisipasi dalam seluruh rangkaian kegiatan pengabdian ini.

\section{DAFTAR PUSTAKA}

Hasan, S. and Anggraeni, P. (2007). Matematika Paket B Kelas VIII, PT Perca, Jakarta Timur.

Hidayat, A. (2010). Matematika X untuk Program Belajar Paket C Setara SMA Kelas X, CV Arya Duta, Depok.

Hidayat, A. (2015). Matematika XI untuk Program Belajar Paket C Setara SMA Kelas XI, CV Arya Duta, Depok.

Polya, G. (1975). How to Solve It: A New Aspect of Mathematical Method, Princeton University Press, Princeton.

Sumarjaya, I. W., Joni, M., Rupiasih, N. N., dan Sibarani, J. (2015). Meningkatkan Kemampuan Pemecahan Masalah Matematika Siswa Paket B dan C di PKBM Mentari Fajar, Laporan Akhir Hibah Udayana Mengabdi (Tidak diterbitkan), Kampus Bukit Jimbaran, Universitas Udayana.

Yuaelawati, E., Syihab, U., Kamil, M., Priatna, N. and Nugroho, S. P. (2008). Acuan Proses Pelaksanaan dan Pembelajaran Pendidikan Kesetaraan Program Paket A, Paket B, dan Paket C, Direktorat Pendidikan Kesetaraan, Direktorat Jenderal Pendidikan Non Formal dan Informal, Departemen Pendidikan Nasional, Jakarta. 